\title{
Ideas y políticas económicas en Colombia durante el primer siglo republicano
}

\author{
Title: Ideas y políticas económicas en Colombia durante el primer siglo republicano \\ Authors: Andrés Álvarez and Juan Santiago Correa (eds.) \\ Edition: Ediciones Uniandes, 2016, 257 pp. \\ ISBN. 9789587742411 \\ Erich PINZÓN-FUCHS \\ Université Paris-I Panthéon-Sorbonne, Center for the History of Political Economy at Duke
}

In his famous 1815 "Letter of Jamaica", and after three centuries of Spanish plundering and yoke, of indigenous extermination and of African slavery, of political restrictions, social barriers and economic privation, Simón Bolívar $(1815$, p. 13) finally declared that "the destiny of America [had] been irrevocably decided; the tie that bound her to Spain [had] been severed". More than thirteen years of war against Spain had been necessary for the criollos (creole revolutionaries) to aspire to a free republic with democratic and liberal institutions that would found the Great Colombia, unifying the territories of today's Colombia, Ecuador, Panama and Venezuela. Given the cultural, geographical, political and economic heterogeneity of this vast territory, however, the foundation of a republic would not come about "through divine miracle", but through "sensible action and well-organized effort" (p. 29). Using a complex lens that encompasses not only economic and political history, but also the history of economic and political ideas during the first century of the Colombian republic (1810-1920), Álvarez and Correa's Ideas y políticas económicas en Colombia durante el primer siglo republicano studies how the new liberated criollos not only conceived and discussed about ideas, but also embarked in "sensible action" performing "well-organized efforts" to found a strong and democratic state out of the bankrupted and fragmented, but optimistic former colonies of northern South America.

The book shows that this was not a simple task. The criollos confronted not only the immediate material problems and the political disorders left after the war for independence, but also "the annals of every period of history", which revealed, as Bolívar (1815) put it, that while "most free nations [had been] subjected to the yoke [...] very few subject nations [had recovered] their freedom" (p. 23). And yet, despite the convictions of history, "South Americans [...] manifested [their] inclination to establish liberal and even perfect institutions, [...] achieved in civil societies founded on the principles of justice, liberty, and equality" (ibid.). The book stands for a suitable compilation of eight articles, which, brought together in two parts, discuss some of these efforts to found liberal institutions that were, nevertheless, far from being perfect. The emphasis is on the design and implementation of a political, a fiscal and a monetary system that would bring liberty to the citizens of the new republic, and order and stability to the new government, opening, in addition, a place for Colombia in the world economy.

Yet, following the enthusiasm and optimism for independence, a whole century -or two- of social, institutional and political disorder derived, characterized by the confrontation of national and regional liberal and conservative forces, pushing away the dreams of liberty, stability and economic takeoff. The criollos, hence, understood that pure intellectual, theoretical and abstract discussions of ideas were of no help in their laudable task. They realized, instead, that pragmatic thinking and action would provide solutions to the concrete problems imposed by the foundation of a new republic. Indeed, the book suggests that the ideas and actions of the criollos are to be found in the republican institutions they designed and established. Unlike other intellectuals in the world, the criollos rarely produced treatises in political economy, philosophy or other branches of knowledge -except for literature-; yet, as is the case in the rest of the world, the ideas of the Colombian scientific and intellectual communities are evidenced in the products of their actions, which, in this case, are the resulting institutions of the new republic. The criollos, however, should not be seen only as intellectuals, politicians, and journalists eager to build lib- 
eral institutions, but also as merchants, traders and bankers, seeking to construct their own commercial institutions and markets.

Given the close connection between the intellectual and commercial criollos with the political power, the first part of the book studies the relation between the state and the market in the formation of Colombian liberal economic thought. Jimena Hurtado (chapter 1) offers a refreshing account of a well-known Colombian criollo: Ezequiel Rojas (1803-1873). Through a detailed scrutiny of the programs proposed by Rojas for the study of political economy in Colombian universities, Hurtado presents Rojas not only as an original intellectual and educator of political ideas, but also as a disseminator of economic ideas. Inscribed in the French sensualistic tradition, Rojas's economic thinking represents a break with both the scholastic tradition inherited from the colonial times, and the English classical school of economics. Chapter 2 evidences Rojas's influence in Colombian politics and economics, focusing on the contributions of one of his former students: Salvador Camacho Roldán (1827-1900). In this chapter, Miguel Urrutia focuses on Camacho Roldán's empirical work and on his interest in statistics, which allowed him to make concrete policy propositions (p. 71). Providing an example of the criollos' pragmatism, this chapter offers an image of nineteenth century Colombia through a comparison of Camacho Roldán's data with contemporary data reconstructions. This, of course, is significant, but given the nature and the purpose of the book, one might get the impression that there is more to say about the use of statistics in the construction of the Colombian state. As Alain Desrosières (1998) showed, statistics not only describe the world, but they also "make up things that hold". Concrete political action upon certain phenomena needs of the intervention of the statisticians in order to turn concepts like "wealth" or "production" into measurable objects and into "objective phenomena". Social objects, like states, in the process of being constructed must be convened, measured and then quantified. This is not to say that states are entirely social constructions; they are simultaneously real and convened. Camacho Roldán's empirical work is definitely an invitation to study the production of statistics in Colombia from this perspective.

Roberto Junguito (chapter 3) discusses the construction of the fiscal system and the implementation of the income tax, placing Colombia in an avant-garde position in terms of modern economic ideas. Junguito, too, studies the fierce opposition exerted by the landowning oligarchy that considered this tax an "oppressive, despotic, and anti-political" institution (p. 106). Edwin López and Salomón Kalmanowitz (chapter 4) revise the discussion about the configuration of a federal or centralized state, and show how the final instauration of a federal system (1858-1886) favored regional elites through the allowance of a free banking system, the establishment of regional currencies and armies, and the inducement of countless civil wars, which resulted in the splitting of the Great Colombia.

The second part of the book focuses on the organization of the monetary and financial system in the nascent republic. Arguing that the construction of a monetary system cannot be understood independently of the political order, Andrés Álvarez (chapter 5) challenges the traditional Colombian monetary history in its claim that a free banking system based on spontaneous private emission existed, which was operational and successful. Chapter 6 contributes to demystifying the idea that free banking dominated the intellectual scene in $19^{\text {th }}$ century Colombia. With his discussion of the creation of national banks (bancosnacionales), Juan Carlos Acosta puts some flesh on the meager historiography of the early Colombian banking system, which, almost exclusively, concentrates on the free banking alternative implemented by the radicals. Acosta shows that "monetary thinking" in Colombia is impressed in the history of the institutions and political practices of the criollos, and that it does not account for "elaborated theoretical constructions, or complex systems of ideas" (p. 185).

Another important episode in the establishment of a Colombian banking system was the creation of the Banco Nacional (National Bank) in 1870 with the arrival to power of the conservative government during the period known as La Regeneración (The Regeneration). As noted by Santiago Correa (chapter 7) the National Bank fulfilled an important political function as an instrument to centralize power (229). Studying the monetary system and its relation to the changing political regimes, Correa argues that the debates on the creation of monetary institutions in Colombia was not so much about economic theory, but rather about the nature and character of the state itself. Somehow disconnected from the emphasis of the rest of the book on the 
Colombian case, the last chapter discusses the work of a foreign money doctor: Edwin Walter Kemmerer (1875-1945). Gómez-Betancourt and Drake claim that Kemmerer should be understood not only as a money doctor, but also as a theoretician. Yet, the relation between Kemmerer's theoretical contribution of a monetary system adaptable for smaller economies -the Gold Exchange Standard- and his visit to Colombia resulting in the creation of the central bank, are, unfortunately, not clearly specified.

Beautifully edited, this book is a worthwhile read for a large audience of economists, historians and social scientists with sufficient bases in Spanish. The book, too, evidences the renovated interest in the history and methodology of economics in Latin America -embodied, also, in the recent creation of the Latin American Society for the History of Economics (ALAHPE)-, which consists in the overcoming of the comparison of central and peripheral ideas, combining an approach based on the study of scientific practices and political action with elements of economic, political and social history that allows for the discovery of original Latin American authors. Because of its scope, the book omits aspects of Colombian history that might have been relevant to the narrative: the maintenance of slavery after independence; the role of the native peoples, peasants and other communities in the creation of a state; the construction of a statistical system, etc. These omissions, however, should not be seen as a weakness of the book, but as an invitation to join the editors' -and the reviewer's- hope that this book will constitute the first piece of a collection that should continue to consolidate the history of economics in Colombia, focusing, this time, not only on historical, but also on methodological aspects of both the $19^{\text {th }}$ and the $20^{\text {th }}$ centuries.

\section{References}

Bolívar, Simón 2003 [1815]. The Jamaica Letter. In Bushnell, David (ed.) and Fornoff, Fred (trans.), El Libertador: writings of Simón Bolívar. New York, Oxford University Press, 1230.

Desrosières, Alain 1998. The Politics of Large Numbers. Translated by Camille Naish. Cambridge, MA, Harvard University Press. 